\title{
混獲防御装置（SURF-BRD）付トロールの 魚種分離とサイズ分離
}

\author{
梶川和武，藤石昭生，永松公明，東海正，松田晈
}

(1998 年 7 月 7 日受付)

\author{
Species- and Size-selectivity of SURF-BRD Trawl \\ Yoritake Kajikawa, ${ }^{* 1}$ Akio Fujiishi, ${ }^{* 2}$ Kimiaki Nagamatsu, ${ }^{* 2}$ \\ Tadashi Tokai, ${ }^{* 1}$ and Ko Matuda*1
}

\begin{abstract}
This study describes species- and size-selectivity of SURF (System of Unwants Ramp-way Filter)-BRD, which was developed to avoid by-catch of juvenile fishes smaller than marketable size and small crabs of no-commercial value in a shrimp beam trawl. The SURF-BRD comprised of two square-mesh panels (FP, front panel and RP, rear one of $40 \mathrm{~mm}$ mesh bar) and two escape-vents, and was installed on the bottom part of the net-mouth. Eleven tows with escape-vent cover-nets for catching escapees from the vent were conducted under three panel conditions: 5 tows with the FP and RP; at 4 tows, rear cover (RC) of the same mesh size as the codend was attached over the RP to avoid animals passing through the RP; 2 tows without the FP to examine the role of FP on selectivity of the device. The results of proportions caught in the codend to the total by species and by animal size indicated three routes of the animals to the codend: 1) swimming above the BRD without encountering the FP; 2) encountering the FP once and retained by it; and 3) passing through the FP and also through the RP. The RP needs to have enough small mesh like the RC, to lead animals out of the net through the escape-vent after passing through the FP. The SURF-BRD allowed some juvenile fishes and small crabs to escape from the net, while catching small shrimp of the main target species at night.
\end{abstract}

キーワード：小型底电網，混獲防御，分離漁獲，選択性

現在，世界の各地で，小型魚を保護することや希少動 物の混獲を防ぐことを目的として，トロール網内に扔い て漁獲物を種や魚体の大きさによって分離する装置 (Bycatch reduction device, BRD) が多数開発されてい る（例えば，TED, 年角目網, ${ }^{2)}$ Nordmøre grid, ${ }^{3)}$ Sort-

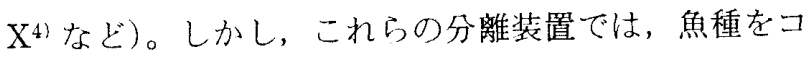
ッドエンド付近で分離するために，そこに到る網内で漁 獲物が相互に或いは網と接触与ることで魚体に稘が付 き, 逃避後の生残率が低下する可能性が指摘されてい る。占とこで，著者らは円滑な分離を行うためには，漁 獲物がコッドエンドに到達する過程の中で，かなり早い 段階に，また，広い空間を確保できる漁具部位で分離を 行う必要があると考え, 網口付近で分離する構造の装置 を開発することにした。沿岸域に打ける主要漁業の1
つである小型底电網「手繰第 2 種漁業」の混獲防御装 置の開発に着手し，火の第一段階上して一階部分の網几 をポリエチレン製の角目網地で覆った二階式絧を試作し た。操業実験の結果6 ${ }^{6}$ 地，二階式網の一階部分のコッ ドエンドを開放して操業すれれば，市場価值がなく船上浧 別の障害となる小型力二類の的 8 割を逃避させること ボできると推测される。一方，主漁獲対象種である小型 エビ類や有用種であって, 大型個体の漁獲の減少がは上 んどないと推察される。しかし，二階式網には次の 2 つの問題点が残った。すず，ひとつは二階式網では構造 が複雑であるために操業時の扱いや破網した際の修理が 困難であり，このことが漁業者への普及の障害となる可 能性がある。もうひとつは二階式網の一階部分のコッド エンドを開放して魚を逃が揚合では，上述した他の分

*1 東京水産大学海洋生産学科 (Department of Marine Science and Technology, Tokyo University of Fisheries, Konan, Minato, Tokyo 108-8477, Japan).

*2水産大学校海洋生産管理学科 (Department of Fishery Science and 'Technology, National Fisheries University, Nagatahonmachi, Shimonoseki, Yamaguchi 759-6595, Japan). 
離装置同様に網内で漁獲物が相互に，或いは網と接触す ることで，網口からコッドエンドに到達する間に逃避魚 の魚体が傷つけられる可能性がある。

そこで，本研究では，これらの欠点を改善するため に，二階式網での成果をふまえて，より単純な構造であ り，かつ網口付近で分離した生物をできるたけ早く網外 に排除する装固 SURF-BRD (System of Unwants Ramp-way Filtered By-catch Reduction Device) を考案 した。このSURF-BRDを装着した試作網を用いて操 業実験を実施して，得られた漁獲資料加ら本装膡のサイ 入゙選択機能を把握する。また，魚種の遊泳特性を考慮に 入れて, 魚種別の分離機構を考察し, 本装固の魚種分離 機能を明らかにする。

\section{材料と方法}

SURF-BRD 試作網の設計と構造 SURF-BRDは山 型に組み合わされた 2 枚の角目網地と逃避口から成り， 網口下部に設置される。SURF-BRDを装着した試作網 の設計図をFig. 1 に示し，その概略をFig. 2 に示す。 この網の網口及び本体の規模は前報6)の二階式網と差が なく, 主要な各部の目合も同じである。しかし, 本漁具 には二階式網にみられた中仕切り網がなく，これに代 り, SURF-BRD が取り付けられている。ここでは 2 枚 の角目網のうち，網口に面した前面をフロントパネル，
後面をリヤパネルと呼ぶ（両パネルとも脚長 $40 \mathrm{~mm}$ )。 さらに，フロントパネルを通過した魚の逃避ロとして， フロントパネルとリヤパネルが形成する身網両側の三角 形状の開口部分を確保した構造とした。また，両パネル で形成される「山型」の稜線の両端部は筋綱に結び付け られている (Fig. 2)。このような構造にすることで， 漁獲物がコッドエンドに到達する過程で，かなり早い時 期に，かつ，広い空間を確保できる網口で分離を行う二 階式網の特徵を維持し，更に，分離した後，できるたけ 早い時期に小型魚を網外に逃避させることができる。こ のため，本装置では二階式網よりも魚体を傷つける機会 が少なくなり，逃避後の生残率が高くなることが期待さ れる。5) また，フロントパネルを通過した小型個体がリ ヤパネルも通過して、コッドエンドで漁獲されることを 防止するために，コッドエンドと同じ目合のリヤカバー （菱目目合 $27.5 \mathrm{~mm}$ ） でリヤパネルを覆った。このリヤ カバーの装着では，まずリヤパネルとリヤカバーの周囲 を縫い合わせ，さらに，これら2枚のパネルの間に空 間が生じないように，約 $20 \mathrm{~cm}$ 間隔をとった 30 個所ほ どで，互いの結節を結び付けた。なお，リヤカバーを装 着した場合は，実用化段階においてはコッドエンドと同 じ目合のリヤパネルを用いた場合を表している。本研究 ではこの構造を串用化段階での基本型と考えている。こ こで,リヤパネルの網目を小さくした場合の効果を調べ



Fig. 1. SURF-BRD trawl net designed to separate marketable fish from non-commercial fish. Note: SURF-BRD, System of Unwants Ramp-way Filtered By-catch Reduction Device. 


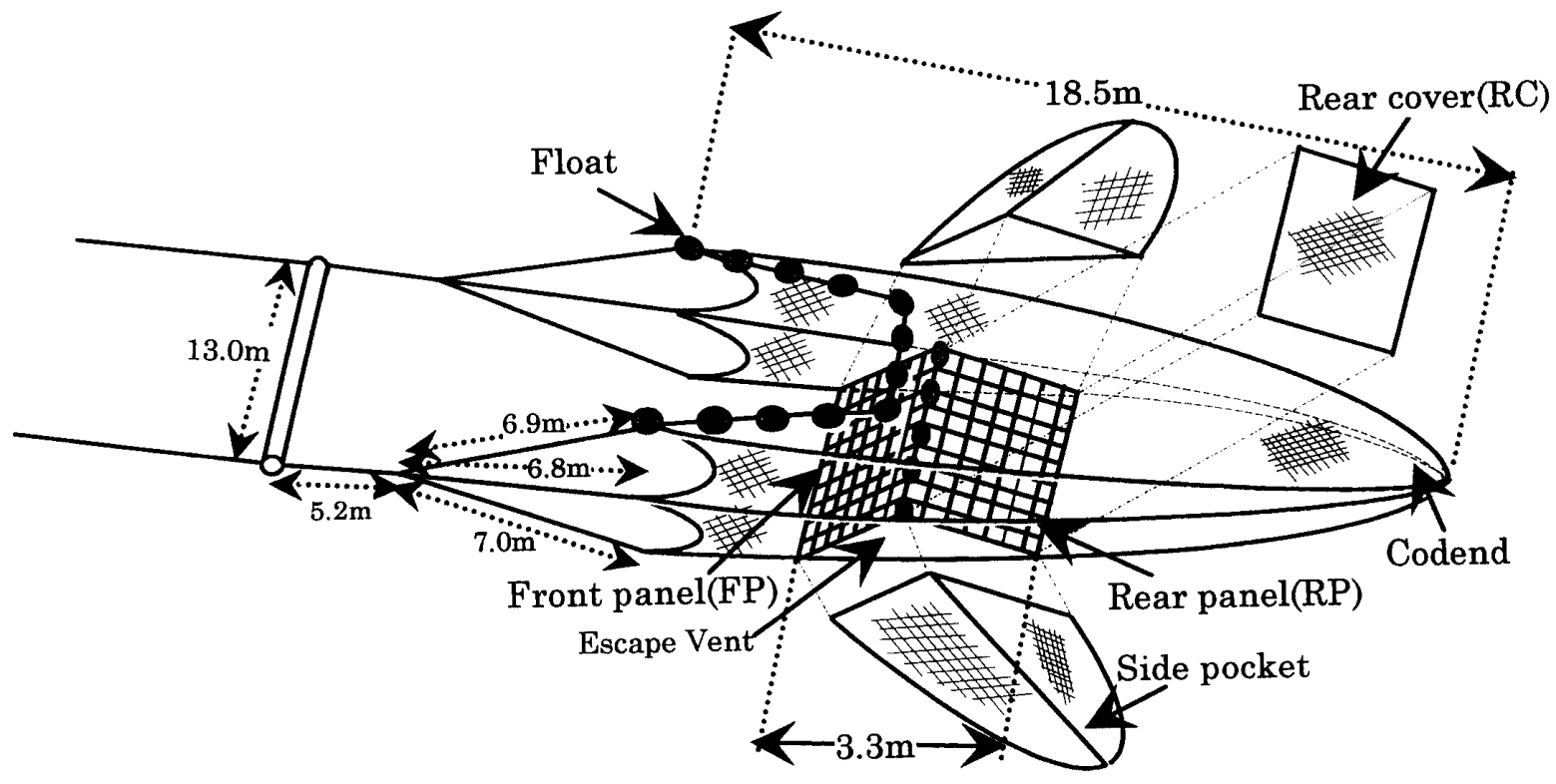

Fig. 2. SURF-BRD mounted in a shrimp beam trawl.

るためには，电網実験に才いてリヤパネルの目合を大き くした場合と比較する必要がある。したがって，本研究 では双方のパネル構成を船上でスムーズに設定できるよ うに，リヤカバーを用意した。

二階式網では一階と二階の間に取り付忛た中仕勿り網 の高さが分離の効果に影響を及ぼした。7,8)このことか ら，本装置で確実な分離を行うためには曳網中の SURF-BRD の高さ（以後, BRD 高さと略称）を一定 に保持させる必要がある。そこで， BRD 高さを一定に 保持させる手段の一つとして, 本漁具のブライドル構成 には 3 本ブライドル方式を採用し，中央ブライドルに より脇網中央部に取り付けた筋綱にワープ張力の一部を 层えている(Fig. 2)。な拉，Fig. 2 ではフロントパネ ルを通過して逃避口から逃げた個体を回収するために, 袋網（サイドポケット）がそれぞれの逃避口に取り付け られている。このサイドポケットは調査用の付属具であ り，実用上は使用しない。

操業実験 1996 年 7 月 1 日と 2 日の昼夜 2 日間に, 小型底电網漁船第三海幸丸（2.9t）を傭船して操業実 験を実施した。操業海域は下関市西沖（北緯 $34^{\circ} 03 \sim$ $05^{\prime}$ ，東経 $130^{\circ} 50 \sim 51^{\prime}$ ) であり，その水深は $20 \sim 30 \mathrm{~m}$ の範团内であった。当海域は 1995 年に実施した二階式 網の実験海域6)とほぼ同じ位固にあり，本漁船が通常操 業している海域でもある。実験条件の概要をTable 1 に 示した。本実験ではSURF-BRD のパネルの構成を 3 つの条件（基本構成であるフロントパネルトリヤパネル +リヤカバー，リヤカバーの効果を調べるためのフロン トパネル十リヤパネル，さらにフロントパネルの効果を 調べるためのリヤパネルのみ）に変えて，それぞれ4
回，5 回，2 回の合計 11 回の曳網を実施した。

前述したように，二階式網の分離効果は中仕町り網の 高さに影響されることが分かっている。五)したがって， 本試作網でも，电網中の網口高さ及び BRD 高さは SURF-BRD の分離効果に影響を及ほす要因の一つと考 えられる。そこで，本研究では电網中の BRD 高さ及び 網口高さを次の方法で計測した。侏アレック電子製メモ リー式深度計（分解能士 $4 \mathrm{~cm}$, 型式 MDS-TD）をヘッ ドローフ, フロントパネル上端, グランドロープの中央 部の 3 力所に設固し，曳網中の深度記録を 1 分間隔で 同時に記録して，それぞれの深度差から，網口高さと BRD 高さを求めた。また，これらの両部位の高さは曳 網速度により変化すること年名から, 电網速度を計测す るために，船上から木片を海上に投棄して，この木片が 一定区間を流れる時間を測定し，船の対水速度を求める 流木試験を 1 回の曳網につき， 3 回実施した。そして， この 3 回の計測に打ける平均値を各曳網の曳網速度と した。

漁獾物の測定 海上㬰験におらる11回の电網で，各 曳網回ごとに全ての漁獲物を漁獲部位別（コッドエンド 及びサイドポケット）に分けて研究室に持ち帰り，冷凍 保存した。冷凍保存した漁獲物は後日解凍し, 魚種別に 分けてそれぞれの尾数を調べた後に，曳網毎に魚種別の 重量を測定した。漁獲尾数が 50 尾を超えた場合には無 作為に抽出した標本 50 尾を，漁獲尾数が 50 尾以下の 場合には全ての魚体の体長と体重を計測した。体長の測 定部位として，魚類では全長，尾叉長，肛門前長のいず れかを，また，エビ類では頭胸甲長，カ二類では甲幅ま たは甲高を採用した。イカ類では外套背長及び体重を測 
定した。

分離事 得られた資料から本装直の分離結果を表わす ために，昼夜別，パネルの構成別，魚種別にコッドエン ドとサイドポケットでの全漁獲尼数に対する各部位での 漁獲尾数の割合を百分率で求めて，これをコッドエンド 及びサイドポケットの各部位における分離率上定義し た。特に, コッドエンドでの漁獲尾数の割合をコッドエ ンド分離率と呼ぶ。なお， SURF-BRD は網口の下側に 位置するので，入網したすべての個体がフロントパネル に遭遇するとは限らない。つまり，コッドエンドで漁獲 された個体にはフロントパネルを通過しなかったものだ けでなく，フロントパネルよりも高い位置を遊泳した個 体やフフロントパネルを通過して，さらにリヤパネルや リヤカバーを通過した個体も含まれる。したがって，こ こでのコッドエンド分離率は，フロントパネルの網目選 択性のみを表したものでなく，フロントパネルに遭遇す るかどうかや，リヤパネルおよびリヤカバーの網目選択 性の効果をも含んでいる。

\section{結果と考察}

SURF-BRD と棢口高さ BRD高さが二階式網の一 階部分と同じ高さの䄪 $1 \mathrm{~m}$ に保持できれば，SURF$\mathrm{BRD}$ は二階式網と同様な分離効果が期待される。年多) パ ネルの構成条件別に一例ずつ曳網中の SURF-BRD と 網口の高さを経時的に示した（Fig. 3)。曳網中の網口 高さは䄪 $2.5 \mathrm{~m}$ であり，BRD 高さは䄪 $0.5 \mathrm{~m}$ である。 これらの值は，時間が経過するにしたがって，同じょう に低下する傾向を示した。しかし，Fig. 3 の例で，両部 位の高さは，パネルの構成の違いにより異なり，フロン トパネルがない場合で最も高く，以降，フロントパネル とリヤパネルとリヤカバーの場合，フロントパネルとリ ヤパネルの場合の順に低くなった。実験中の各曳網で得 られた両部位（網口高さとBRD 高さ）の曳網中の平均
高さを Table 1 に示す。これによれば, Fig. 3 に示した 例のように,フロントパネルがない場合の両部位の高さ は他の場合に比べ大きい。しかし，フロントパネルとリ ヤパネルとリヤカバーの場合とフロントパネルとリヤパ ネルの場合では各条件内における両部位の高さは 10 $20 \mathrm{~cm}$ 程度の変動があるために，両条件間における両部 位の高さの差は明らかでない。そこで, リヤカバーの有 無によって両部位の高さに差がないとする帰無仮説を立 てて， $t$ 検定を行ったが，両部位とむに有意水準 $5 \%$ で 帰無仮説を棄却できなかった（網口高さ $t=0.1068$, $\mathrm{BRD}$ 高さ $t=0.8075, \phi=7, p>0.05)$ 。したがって，リ ヤカバーの有無による両部位の網口高さには差がないと 考えられる。

ここで, フロントパネルがない場合に両部位が高くな った原因として，次のことが考えられる。Fig. 2 に示し たようにフロントパネルは曳網方向に対して，海底面か ら鈍角に取り付けられている。このため, 电網中に網内 に生じる水流によってフロントパネルに下向きの掦力が 動くと考えられる。フロントパネルがない場合は海底面 から曳網方向に対して鋭角に取り付けられているリヤパ ネルに対して直接に水流が当たり，上向きの揚力が働く と考えられる。この結果, フロントパネルなしの場合で BRD 高さが大きな值を示したと考えられる。

魚種別の分離結果 操業実験で得られた漁獲物の概要 は，魚類 62 種で $77.7 \mathrm{~kg}$, 甲殼類 33 種で $97.2 \mathrm{~kg}$, 頭 足類 6 種で $21.0 \mathrm{~kg}$ ，その他 4 種で $0.7 \mathrm{~kg}$ の合計 196.6 $\mathrm{kg}$ であった（Table 2)。上記の漁獲物の中から漁獲尾 数が多かった魚類 6 種と，甲殼類 5 種，頭足類 1 種を 取り上げて，これらの種に抢ける両部位の分離率を冝夜 別に求めた（Fig. 4)。むす，夜間操業時の各魚種の分 離率を検討する。魚類 6 種のうち，カナガシラ Lepidotrigla microptera， オキヒイラギLeiognathus rivulatus, エソ類 Saurida spp., テンジクダイApogon

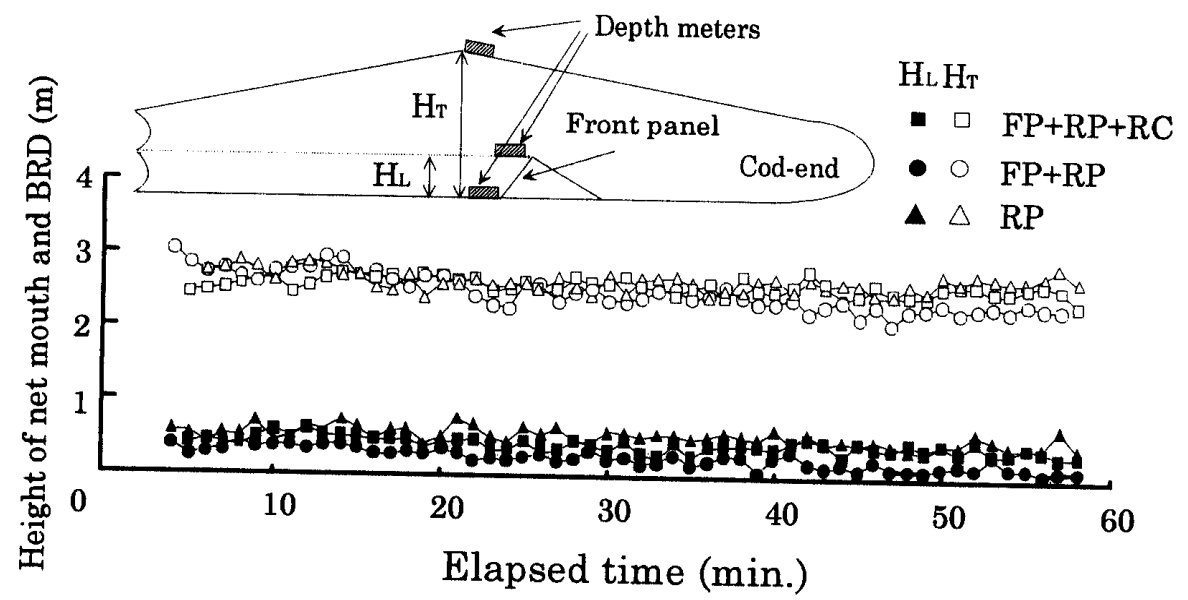

Fig. 3. Height-time sequential records of the net mouth and SURF-BRD during towing. 
Table 1. Outline of experimental hauls by the beam trawl with SURF-BRD

\begin{tabular}{|c|c|c|c|c|c|c|c|}
\hline \multirow[b]{2}{*}{ Houl no. } & \multirow[b]{2}{*}{ Panel condition* } & \multirow[b]{2}{*}{ Date } & \multirow{2}{*}{$\begin{array}{l}\text { Day or } \\
\text { Night }\end{array}$} & \multirow{2}{*}{ Towing time } & \multirow{2}{*}{$\begin{array}{l}\text { Average of towing } \\
\text { speed (Knot) }\end{array}$} & \multicolumn{2}{|c|}{ Height (m) } \\
\hline & & & & & & Net mouth & SURF-BRD \\
\hline 1 & \multirow{4}{*}{$\mathrm{FP}+\mathrm{RP}+\mathrm{RC}$} & \multirow{4}{*}{$\begin{array}{c}\text { 1/July } \\
1996\end{array}$} & \multirow{2}{*}{ Day time } & $15: 33 \sim 16: 28$ & 2.2 & 2.41 & 0.45 \\
\hline 2 & & & & $16: 50 \sim 17: 43$ & 2.1 & 2.53 & 0.35 \\
\hline 3 & & & \multirow{2}{*}{ Night time } & $18: 04 \sim 19: 03$ & 1.9 & 2.51 & 0.45 \\
\hline 4 & & & & $19: 51 \sim 20: 41$ & 1.7 & 2.38 & 0.35 \\
\hline 5 & \multirow{5}{*}{$\mathrm{FP}+\mathrm{RP}$} & & \multirow{2}{*}{ Night time } & $21: 45 \sim 22: 44$ & 1.7 & 2.30 & 0.30 \\
\hline 6 & & & & $23: 07 \sim 24: 05$ & 2.1 & 2.42 & 0.40 \\
\hline 7 & & \multirow{3}{*}{$\begin{array}{c}\text { 2/July } \\
1996\end{array}$} & \multirow{2}{*}{ Day time } & $16: 30 \sim 17: 37$ & 2.3 & 2.54 & 0.47 \\
\hline 8 & & & & $17: 50 \sim 18: 50$ & 1.2 & 2.39 & 0.30 \\
\hline 9 & & & Night time & $19: 45 \sim 20: 44$ & 1.8 & 2.27 & 0.35 \\
\hline 10 & \multirow{2}{*}{$\mathrm{RP}$} & & \multirow{2}{*}{ Night time } & $21: 14 \sim 22: 14$ & 1.7 & 2.60 & 0.52 \\
\hline 11 & & & & $23: 30 \sim 23: 29$ & 1.8 & 2.58 & 0.57 \\
\hline
\end{tabular}

* FP, Front panel; RP, Rear panel; RC, Rear cover.

Table 2. Catch number and weight in the fishing experiment

\begin{tabular}{|c|c|c|c|c|c|c|c|c|c|c|c|c|}
\hline \multirow{2}{*}{$\begin{array}{c}\text { Panel } \\
\text { condition* }\end{array}$} & \multirow{2}{*}{$\begin{array}{l}\text { Number } \\
\text { of tows }\end{array}$} & \multirow[b]{2}{*}{ Bag } & \multicolumn{2}{|c|}{ Fish } & \multicolumn{2}{|c|}{ Crustacean } & \multicolumn{2}{|c|}{ Molluscan } & \multicolumn{2}{|c|}{ Others } & \multicolumn{2}{|c|}{ Total } \\
\hline & & & $\begin{array}{c}\text { Weight } \\
(\mathrm{kg})\end{array}$ & Number & $\begin{array}{c}\text { Weight } \\
(\mathrm{kg})\end{array}$ & Number & $\begin{array}{c}\text { Weight } \\
(\mathrm{kg})\end{array}$ & Number & $\begin{array}{c}\text { Weight } \\
(\mathrm{kg})\end{array}$ & Number & $\begin{array}{l}\text { Weight } \\
(\mathrm{kg})\end{array}$ & Number \\
\hline \multirow{2}{*}{$\mathrm{EP}+\mathrm{RP}+\mathrm{RC}$} & \multirow{2}{*}{4} & Cod end & 26.13 & 1663 & 8.93 & 2557 & 7.83 & 301 & 0 & 0 & 42.89 & 4521 \\
\hline & & Side pocket & 1.23 & 129 & 5.10 & 1189 & 0.03 & 2 & 0.01 & 2 & 6.37 & 1322 \\
\hline \multirow{2}{*}{$\mathrm{FP}+\mathrm{RP}$} & \multirow{2}{*}{5} & Cod end & 41.17 & 2026 & 33.46 & 8459 & 7.54 & 176 & 0.26 & 14 & 82.43 & 10675 \\
\hline & & Side pocket & 1.66 & 211 & 14.29 & 3683 & 1.22 & 4 & 0.24 & 15 & 17.41 & 3913 \\
\hline \multirow{2}{*}{$\mathrm{RP}$} & \multirow{2}{*}{2} & Cod end & 5.65 & 384 & 20.71 & 6129 & 0.43 & 13 & 0 & $\begin{array}{c}0 \\
\cdots\end{array}$ & 26.79 & 6526 \\
\hline & & Side posket & 1.86 & 173 & 13.92 & 2877 & 3.88 & 23 & 0.13 & 7 & 19.79 & 3080 \\
\hline Total & 11 & & 77.70 & 4586 & 96.40 & 24894 & 20.93 & 519 & 0.65 & 38 & 195.68 & 30037 \\
\hline
\end{tabular}

* FP, Front panel; RP, Rear panel; RC, Rear cover.

lineatus の 4 種の分離率はパネルの構成により若干の変 動はあるものの，ほとんどの個体がコッドエンドで漁獲 された。一方，異体類のガンゾウビラメPseudorhombus cinnamoneus やアカシタビラメCynoglossus joyneriの 2 種は前述の 4 種に比べて，コッドエンド分 離率が低い。また，各パネルの構成に対して両種のコッ ドエンド分離率も異なり，フロントパネルとリヤパネル とリヤカバーの場合が最も高く（ガンゾウビラメで 78\%，アカシタビラメで 69\%)，以下，フロントパネル とリヤパネル，リヤパネルのみの順に $10 〜 20 \%$ ずつコ ッドエンド分離率が低下した。甲殼類をみると，主漁獲 対象種である小型エビ類のトラエビMetapenaeopsis acclivis とアカエビMetapenaeopsis barbata は両種ともに パネルの構成に関係なく，90\% 以上がコッドエンドで
漁獲された。これに対して，投棄対象種である小型力二 類のヒメガザミPortunus hastatoides とフタホシイシガ 二 Charybdis bimaculata，ヒロハイシガニ Charybdis truncata の3 種は, フロントパネルとリヤパネルの場合 のヒメガザミを除いて，すべて 50\%以上がサイドポタ ットで漁獲された。また，パネルの構成別に見ると，フ ロントパネルとリヤパネルとリヤカバーの場合，コッド エンド分離率は，ヒメガザミで50\%，フタホシイシカj 二で $32 \%$ ，ヒロハイシガニで $27 \%$ を示した。これに対 し，リヤカバーがないフロントパネルとリヤパネルの場 合，コッドエンド分離率は，ヒメガザミで $62 \%$, フタ ホシイシガニで $50 \%$ ，ヒロ八イシガニで $43 \%$ と前条件 に比べ増加傾向を示した。軟体動物のコウイ力Sepia esculentaではフロントパネルが取り付けられている場 


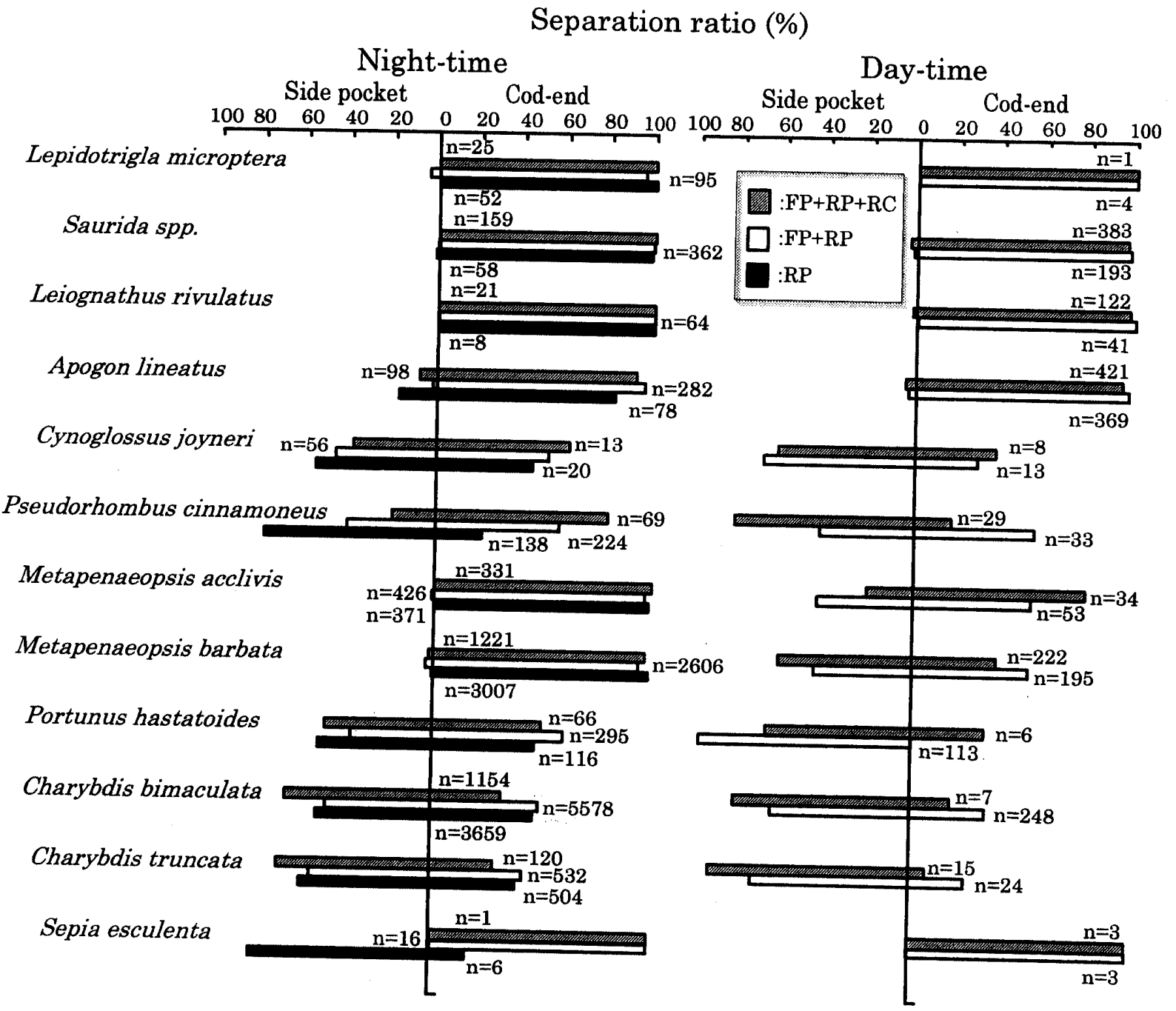

Fig. 4. Separation ratio of SURF-BRD by species and panel conditions.

合，リヤカバーの有無に関わらず，すべての個体がコッ ドエンドで漁獲された。しかし，フロントパネルを取り 外した場合，80\%の個体がサイドポケットに逃避した。 ただ，本種は他種に比へて漁獲尾数が少ないため，分 離率の精度が悪い。

次に，昼間操業時における各魚種の分離率を検討する (Fig. 4)。なお，昼間の場合ではフロントパネルを取り 外した実験を行っていないため，この場合の分離率は求 めていない。カナガシラ, エソ, オキヒイラギ, テンシ クダイでは夜間の分離率と同じ傾向を示し，ほとんどの 個体がコッドエンドで漁獲された。しかし，アカシタビ ラメ，ガンソウビラメでは夜間に比べてサイドポケット に逃避する割合が増加し，フロントパネルとリヤパネル とリヤカバーの場合のコッドエンド分離率はガンゾウビ ラメで17\%，アカシタビラメで38\%であった。また， トラエビ, アカエビやヒメガザミ, フタホシイシガニ, ヒロハイシガニでも，異体類と同様に夜間に比べてサイ ドポケットに逃避する割合が増加し，フロントパネルと
リヤパネルとリヤカバーの場合のコッドエンド分離率は トラエビとアカエビでそれぞれ 79\% と 38\%，また， ヒ メガザミ，フタホシイシガニ，ヒロハイシガニではそれ ぞれ 33\%,19\%,7\%を示した。

Fig. 4 に示した分離率は昼夜及び各パネルの構成間で 漁獲尾数に差があるためにその精度が異なり，それぞれ の条件間における差を正確に表しているとは限らない。 そこで，それぞれの条件間の差を明確にするために，ま ず冝夜における各魚種の分離率に差がないとの帰無仮説 を立てて， $\chi^{2}$ 検定を行った。その結果，力バー付き $(\mathrm{FR}+\mathrm{RP}+\mathrm{RC})$ 及びカバーなし $(\mathrm{FP}+\mathrm{RP})$ の双方 で，㷌無仮説が有意水準 $5 \%$ で棄却された魚種はア力 エビ（カバー付き $\chi^{2}=681.56, \phi=2$, カバーなし $\chi^{2}=$ $30.983, \phi=2, p<0.05$ ), トラエビ（カバー付き $\chi^{2}=$ 58.97, カバーなし $\left.\chi^{2}=147.171, \phi=2, p<0.05\right)$, フタ ホシイシガ二（カバー付き $\chi^{2}=8.338$, カバーなし $\chi^{2}=$ 23.933, $\phi=2, p<0.05$ ), ヒメガザミ（力バー付き $\chi^{2}=$ 5.913, カバーなし $\left.\chi^{2}=5.913, \phi=2, p<0.05\right)$ の 4 種で 
あった。また，ガンゾウビラメではカバー付きの場合の みで帰無仮説が㫧却された（カバー付き $\chi^{2}=30.983$ ， $\phi=2, p<0.05)$ 。一方, ヒロハイシガニで䚻無仮説を棄 却できなかったのは（カバー付き $\chi^{2}=2.397$ ，カバーな 乙 $\left.\chi^{2}=2.324, \phi=2, p>0.05\right)$, 漁獲尾数が少なかったた めと考えられる。以上の結果から，小型エビ類と小型力 二類及びガンゾウビラメの分離率は昼夜で有意な差が認 められた。次に，それぞれの魚種内で， 3 種類のパネル の構成に対して求めた分離率に差がないとの帰無仮説を 立て， $\chi^{2}$ 検定を行った。その結果，夜間の場合，テン ジクダイ $\left(\chi^{2}=29.9308, \phi=2, p<0.05\right)$, ガンゾウビラ メ $\left(\chi^{2}=64.0555, \phi=2, p<0.05\right)$, アカエビ $\left(\chi^{2}=\right.$ $29.9193, \phi=2, \quad p<0.05)$, ヒメガザミ $\left(\chi^{2}=7.8042\right.$, $\phi=2, p<0.05)$, フタホシイシガニ $\left(\chi^{2}=72.9336, \phi=2\right.$, $p<0.05)$, コウイカ $\left(\chi^{2}=18.0435, \phi=2, p<0.05\right)$ の 6 種で有意な差が認められた。さらに、これら 6 種につ いて，リヤカバーの有無による分離率の差を検定した。 その結果, ガンゾウビラメ $\left(\chi^{2}=7.9329, \phi=1, p<0.05\right)$ とフタホシイシガニ $\left(\chi^{2}=80.8721, \phi=1, p<0.05\right)$, ト ラエビ $\left(\chi^{2}=5.1651, \phi=1, p<0.05\right)$ ではリヤカバーの 有無に上り分離率に有意な差が認められた。一方，トラ エビと形態が似ているアカエビ10)ではリヤカバーの有
無によって分離率に有意な差が認められなかった（ $\chi^{2}$ $=2.7443, \phi=1, p>0.05)$ 。 また，昼間の曳網時にフロ ントパネルとリヤパネル, リヤカバーの場合のコッドエ ンド分離率はトラエビとアカエビでそれぞれ $79 \%$ と 38\% と差が生じた。これらの両種間に分離率の差が生 じる理由として，潜砂能力が異なる による可能性が考えられる。

体長別のコッドエンド分離率 上述した分離率は, 二 階式網の実験の結果と同様に，フロントパネルの網目の 大きさによって変化するものと考えられる。6) また，い くつかの魚種でリヤカバーの有無によって分離率が異な ったこと（Fig. 4）からも，フロントパネルのみなら ず，リヤパネルやリヤカバーもサイズ選択性を有した可 能性がある。このことは本装置の分離機構の解明には, 各魚種毎に体長別のコッドエンド分離率を検討する必要 があることを示している。そこで，分離効果を表す指標 として, 網目の選択曲線の表示法に習い, 横軸に体長を とり，縦軸にコッドエンド分離率を示した（Fig. 5)。

Fig. 4 で分離率を示した魚種の中から，魚類については 漁獲尼数が多く，比較的市場価值があるとされる ${ }^{12}$ 工 ソ類とガンゾウビラメを，また，甲殼類では主要漁獲対 象種のアカエビ，投棄対象種のフタホシイシガニ, 頭足

Day and Night-time
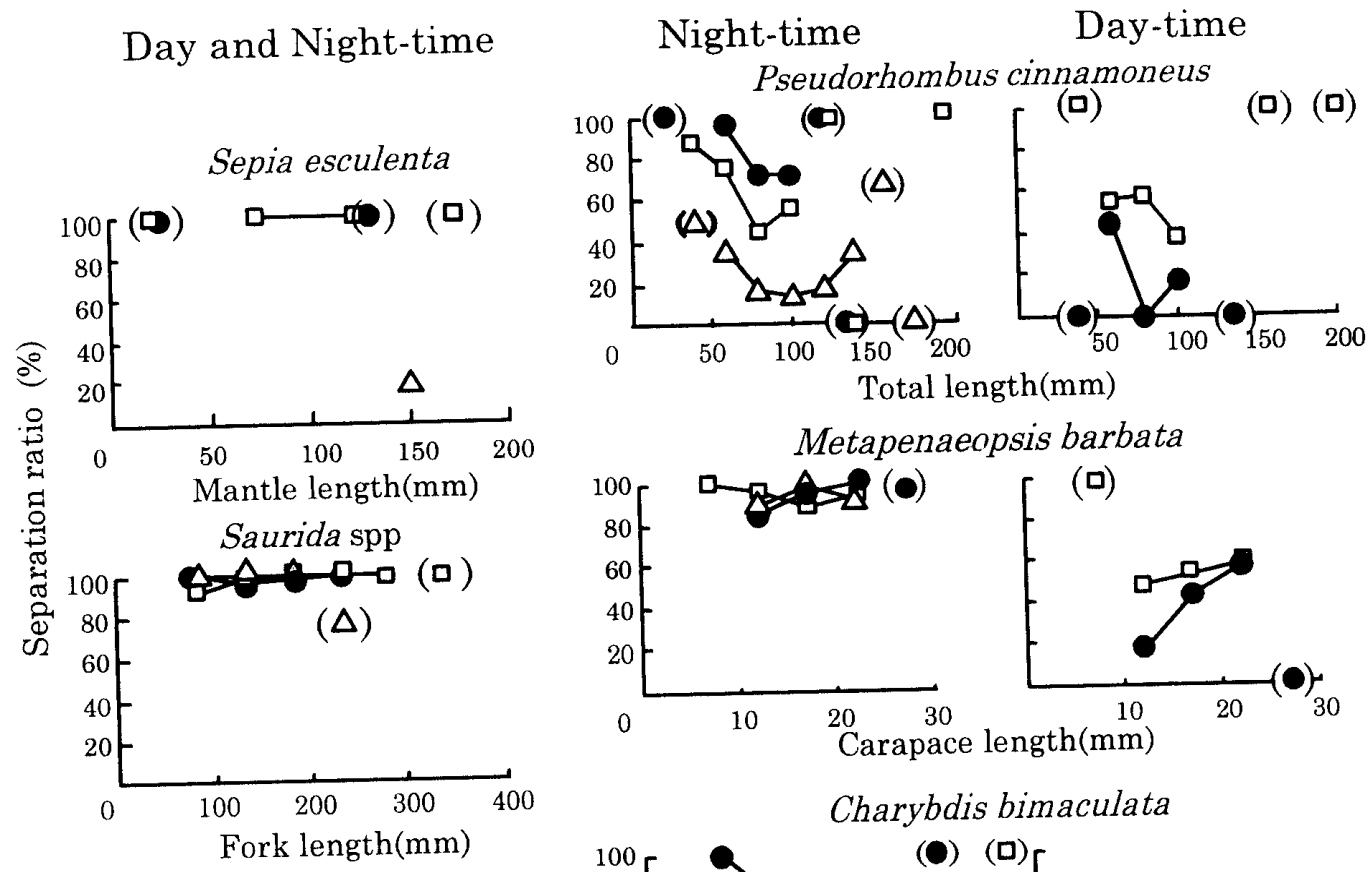

Charybdis bimaculata

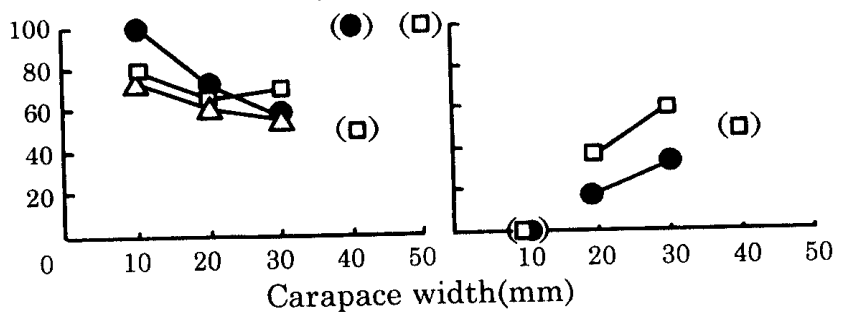

Fig. 5. Plots of separation ratio against body size. 
類については高価格種のコウイカを取り上げた。このう ち，前項に打いて， $\chi^{2}$ 検定で昼夜の分離率に差が認め られたガンゾウビラメ，アカエビ，フタホシイシガニで は冝夜別にコッドエンド分離率を求めた。これを基にし て魚種毎にパネル構成別のコッドエンド分離率の違いを 比較し，それぞれの魚種毎に体長別の分離機構を検討す る。

\section{エソ類ではパネルの構成や魚体の大きさに関係なく，} ほとんどの個体がコッドエンドで漁獲された（Fig. 5)。 フロントパネル，リヤパネル及びリヤカバーの場合を見 ると,この尾叉長 $200 \mathrm{~mm}$ のエソ類は Fujiishi ${ }^{13)} に よ$ る網目選択性の理論曲線から考えると，フロントパネル は通過できても，リヤカバーを通過できない。このこと から，エソ類の遊泳層はフロントパネルよりも高いこと が推測される。一方，コウイカではフロントパネルが取 り付けられている場合，すべての個体がコッドエンドで 漁獲されたのに対して, リヤパネルのみの場合では、コ ッドエンド分離率が $17 \%$ に低下して，ほとんどがサイ ドボケットに入った。したがって, 本装置のパネル構成 が基本型のフロントパネルとリヤパネルとリヤカバーの 時, コウイカのほとんどはフロントパネルに一度遭遇す るもののそこを拔けることなく、コッドエンドで漁獲さ れたと考えられる。アカエビも夜間の場合では, フロン トパネルの網目（脚長 $40 \mathrm{~mm}$ ）に比べて十分に小さい 個体（頭胸甲長 $20 \mathrm{~mm}$ 以下）でも，パネルを通過する ことなくコッドエンドで漁獲された。これに対して，昼 間では同様な頭胸甲長範囲内の個体のコッドエンド分離 率は，夜間に比へてて低く，頭胸甲長が大きくなるにつれ て高くなる傾向を示した。これは冝夜において，これら 種の行動に違いがあることによると考えられる。通常, 小型エビ類は夜間に活動的で，昼間は潜砂してい る。11,14-16) つまり，活動的な夜ではほとんどの個体がグ ランドロープやフロントパネルに接触して跳ね上が り， ${ }^{17-19)}$ フロントパネルを越えてコッドエンドで漁獲さ れたと考えられる。一方, 昼間では潜砂して活動が低下 するために SURF-BRD を越えることなく, フロント パネルに遭遇した結果, より小型の個体が多くフロント パネルを拔けて，逃避したものと考えられる。また，昼 間の場合，頭胸甲長 $10 \mathrm{~mm} \sim 20 \mathrm{~mm}$ の小型個体のコッ ドエンド分離率はリヤカバーがある場合に比べて，ない 場合の方が高い。これはリヤカバーがない場合に, フロ ントパネルを通過した小型個体がフロントパネルと同じ 目合のリヤパネルも通過してコッドエンドで漁獲された と考えられる。これに対して，より小さな網目のリヤカ バーがある場合では，小型個体がリヤカバーを通過でき ずに，逃避ロからサイドポケットに入ったものと考えら れる。ガンゾウビラメのコッドエンド分離率は, 全長の
大きさに対してU 字型に並んた（Fig. 5)。夜間の場合, 全長 $50 \mathrm{~mm}$ 付近のコッドエンド分離率が高い值を示 し，魚体が大きくなるにしたがって，コッドエンド分離 率はいったん低下し，80〜100 mm 付近で最も低い值に なった。それ以降, 魚体が $100 \mathrm{~mm}$ 以上になると、コ ッドエンド分離率が再び增加した。また，フロントパネ ルを取り外したリヤパネルのみの場合のコッドエンド分 離率は 10〜 40\% の間でU 字型を描いて分布しており， 他の場合に比べて低い。この原因はフロントパネルを取 り外した場合の BRD 高さは取り付けた場合に比べて約 4 割増加することから，リヤパネルに遭遇する確率が高 くなり, サイドポケットへ逃避する個体が増加した可能 性が考えられる。一方, コッドエンド分離率が U 字型 を描いた原因は魚体の大きさによって遊泳層が異なる， 或は，魚体が大きくなれば遊浪力が増すために, リヤパ ネルを回避してコッドエンドで漁獲されるなどが推察さ れる。一方, 昼間のコッドエンド分離率は夜間に比べて 低かった。これは本種の昼夜の行動に差がある20)こと による影響であろう。ここで, コッドエンド分離率が U 字型を描いた原因について考察する。東海ら ${ }^{21)}$ は， リヤカバーと同じ目合 $(27.5 \mathrm{~mm})$ の菱目網コッドエン ドのタマガンゾウビラメPseudorhombus pentophthalmus に対する網目選択曲線を求めた。これによ ればこの種の異体類では $25 \%$ 選択体長は $48.3 \mathrm{~mm}$, $75 \%$ 選択体長は $86.3 \mathrm{~mm}$ となる。したがって，本装置 では全長 $50 \mathrm{~mm}$ の小型個体の半数以上がフロントパネ

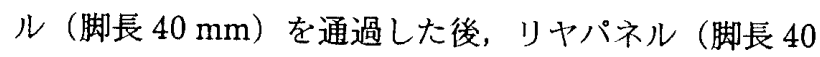
$\mathrm{mm}$ ）及びリヤカバー（目合 $27.5 \mathrm{~mm}$ ）も通過して，コ ッドエンドで漁獲されたものと推察される。全長が 80 $\mathrm{mm}$ になると, フロントパネルは通過するものの, リヤ パネル及びリヤカバーの通過が不可能な個体が増加し て、コッドエンド分離率が低下する。さらに，魚体が $100 \mathrm{~mm}$ 以上になると,フロントパネルを通過できなく なることでコッドエンドに入る割合が增えたと考えられ る。また, フロントパネルを取り外した場合でも，魚体 が大きくなるにつれてコッドエンド分離率が大きくな る。この原因は，魚体の大きさによって遊泳層が異な る，或は，魚体が大きくなれば遊泳力が増すため，リヤ パネルを回避してコッドエンドで漁獲されるなどが推察 される。

フタホシイシガニでは夜間の場合, 甲幅 $20 \mathrm{~mm}$ のコ ッドエンド分離率は 80〜100\% の值を示し, 甲幅 30〜 $40 \mathrm{~mm}$ になるとコッドエンド分離率は 60〜70\%に減 少した。一方, 昼間に抢けるコッドエンド分離率は夜間 より低く，アカエビと同様に甲幅が大きくなるにつれて 高くなる。また，全体的にコッドエンド分離率はリヤカ バーがある場合よりもない方が高い値を示した。これも 


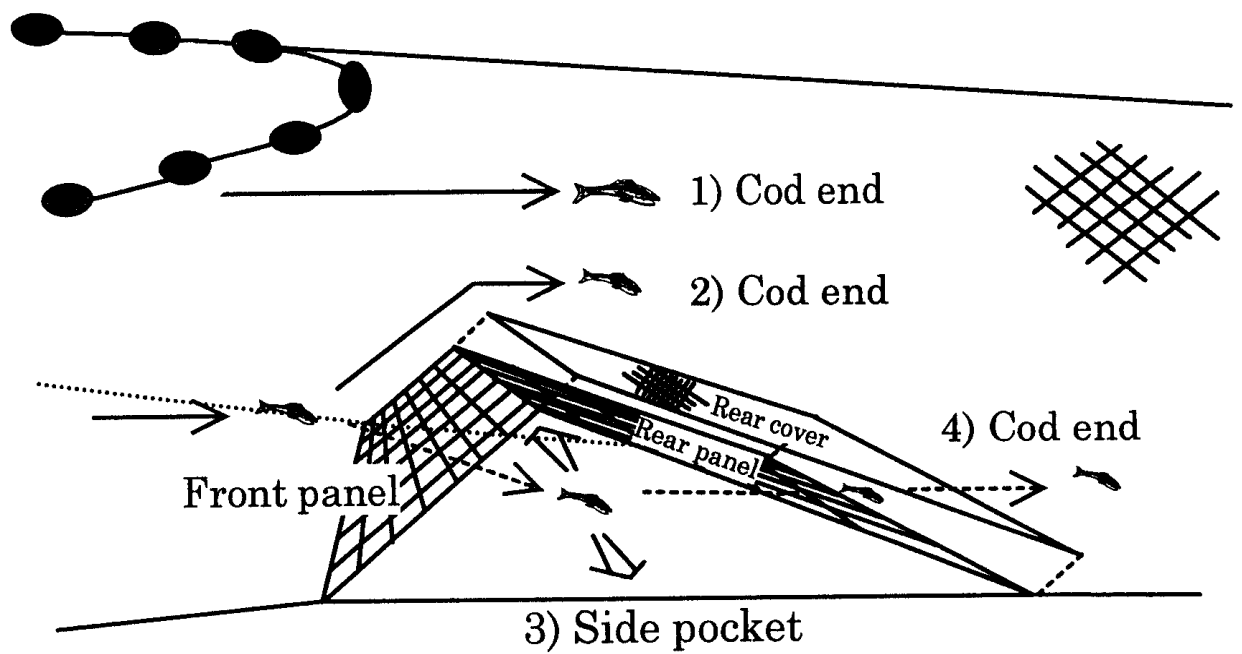

Fig. 6. Schematic diagram of animal behavior against SURF-BRD.

アカエビの場合と同様にリヤカバーの網目選択性による ものと考えられる。

SURF-BRDに対する魚の行動これまで述べてき た分離率や体長別のコッドエンド分離率から， SURFBRD に対する魚の行動パターンを以下の 4 つのパター ンに分類して，模式的に Fig. 6 に示した。

（1）分離装置のフロントパネルの上方を遊泳し，フロ ントパネルに遭遇することなくコッドエンドへ入 る。尾叉長 $200 \mathrm{~mm}$ のエソ類は，フロントパネル がない場合ほとんどの個体がコッドエンドで漁獲さ れたことから，この経路で漁獲されたと推測され る。小型エビ類は夜間では個体に対して十分に網目 が大きいにもかかわらず，100\% 近くの個体がコッ ドエンドで漁獲されたことから，このパターンで漁 獲されたと推定される。また，夜間の場合のガンゾ ウビラメ，小型カ二類のコッドエンド分離率は昼間 に比べて高い值で分布していることから，ある程度 の個体がこの経路で漁獲されたと考えられる。

（2）フロントパネルに遭遇した後，角目網を通過する ことなくパネルに沿って上方へ遊泳して，またはフ ロントパネルを拔けることなく接触しながら、コッ ドエンドへ誘導される。コウイカはフロントパネル の有無によって分離率が左右されることから (Fig. 5), フロントパネルによってコッドエンドへ 誘導されたと考えられる。屯た，全長 $100 \mathrm{~mm}$ 以 上のガンゾウビラメや甲幅 $20 \sim 30 \mathrm{~mm}$ のフタホシ イシガニ，頭胸甲長 $10 \sim 20 \mathrm{~mm}$ のアカエビもこの 経路を経てコッドエンドで漁獲されたと考えられ る。

（3）フロントパネルに遭遇して角目網を通過した後， 逃避口から網外に出る。Fig. 5 に示した全長 80 $\mathrm{mm}$ 前後のガンゾウビラメ, 甲幅 $20 \sim 30 \mathrm{~mm}$ の小 型力二類，昼間における頭胸甲長 10〜20 $\mathrm{mm}$ の小 型エビ類では体長階級別のコッドエンド分離率は， 魚体が大きくなるにつれて低下した。これらの個体 はこの経路を経て網外に逃避したと考えられる。

（4）フロントパネルに遭遇して角目を通過した後に， リヤパネルやリヤカバーの網目も通過してコッドエ

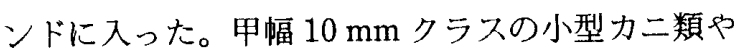
全長 $50 \mathrm{~mm}$ のガンゾウビラメはこの経路を経てコ ッドエンドで漁獲されたと考えられる。

この海域でのエビを対象とする底电網は主に夜間に操 業される。したがって，底电網にSURF-BRDを取り 付ければ，夜間では，电網中に投雍対象種である小型力 二類を逃避させながら, 主要漁獲対象種の小型エビ類を 漁獲できるので，船上での漁獲物の選別作業を軽减化さ せることに役立つ。をた, 体長 $100 \mathrm{~mm}$ 前後のアカシ タビラメやガンゾウビラメを保護できる。しかし，本試 作網は曳網時に抢ける BRD 高さが $1 \mathrm{~m}$ になるように設 計されたが，実際には $0.5 \mathrm{~m}$ 程度であった（Fig. 4)。 この高さではフロントパネルが弛み, フロントパネルの 前端部が接地して，分離機能に悪影響を及ぼした可能性 が考えられる。今後は曳網中の網口高さを維持できるよ うに，設計を改良する必要がある。

\section{謝辞}

本研究を進めるにあたり, 貴重なご助言, ご協力を頂 いた水産大学校海洋生産管理学科 井上 悟博士，操業 実験に協力頂いた山口県下関漁業協同組合の中谷南海男 氏，甲殼類の同定をご指導頂いた水産大学校生物生産学 科 林 健一博士に深く感謝する。 


\section{文献}

1) J. W. Watoson, J. F. Mitchell, and A. K. Shah: Trawling Efficiency Device: A New Concept for Selective Shrimp Trawling Gear. Mar. Fish. Rev., 48, 1-9 (1986).

2) J. H. B. Robertson and P. A. M. Stewart: A comparison of size selection of haddock and whiting by square and diamond mesh codends. J. Cons. Int. Explor. Mer., 44, 148-161 (1988).

3) B. Isaksen, J. W. Valdemarsen, R. B. Larsen, and L. Karlsen: Reduction of fish by-catch in shrimp trawl using a rigid separator grid in the aft belly. Fish. Res., 13, 335-352 (1992).

4) R. B. Larsen and B. Isaksen: Size selectivity of rigid sorting grids in bottom trawls for Atlantic cod (Gadus morhua) and haddock (Melanogrammus aeglefinus). ICES mer. Sci. Sympo., 196, 178-182 (1993).

5）有元贵文：漁業における混獲とは，松田 盿編「漁業の 混獾問題」, 亘星社厚生閣, 東京, 1995, pp. 11-29.

6）梶川和武，藤石昭生，井上悟，永公公明，濱野明： 分離漁獲装固付き小型底曳絧の分離効果. 日水誌，64， 189-196 (1998).

7) J. Main and G. I. Sangster: Trawling experements with a Two-level net to minimise the undersized gadoid by-catch in a Nephrops fishery. Fish. Res., 3, 131-145 (1985).

8）町田末広, 岡座輝雄, 斎藤達彦: 2 段式小型底电網の上下 袋絧に上る分離漁獲. 長崎水試研報, 20, 47-53 (1994)。

9）宮崎千博: 小型機船底电䊀の研究. 三重大水産学部紀要, 2, 98-220 (1957).

10）林 健一：日本産エビ類の分類と生態, 生物研究社, 東 京, 1992, pp. 83-84.

11）阪地英男 : トラエビ, アカエビ, キシエビ及びサルエビ の潜砂能力. 南西水研研報, 28, 1-7 (1994).

12）井上悟, 永松公明, 藤石昭生, 阿部 窗: 下関西沖に
おける小型底びき網漁業の投萧魚. 水大校研報，42,109118 (1994).

13) A. Fujiishi: A Theoretical approach to the selectivity of the net gears-III. J. Shimonoseki Univ. Fish., 23, 87-108 (1974).

14) D. A. Wickham and F. C. Minkler: Laboratory observations on daily patterns of burrowing and locomotor activity of pink shrimp, Penaeus duorarum, brown Shrimp, Penaeus aztecus, and white shrimp, Penaeus setiferus. Contr. Mar. Sci., 19, 21-35 (1975).

15) T. H. Moller and D. A. Jones: Locomotory rhythms and burrowing habits of Penaeus semisulcatus (de Haan) and $P$. monodon (Fabricius) (Crustacea: Penaeidae). J. exp. mar. Biol. Ecol., 18, 61-77 (1975).

16) C. M. Fuss and L. H. Ogren: Factors affecting activity and burrowing habits of the pink shrimp, Penaus Duorarum Burkenroad. Biol. Bull., 130, 170-191 (1966).

17) C. M. Fuss: Shrimp behavior as related to gear research and development. 1. Burrowing behavior and responses to mechanical stimulus, in "Modern Fishing Gear of the World", 2, Fishing News (Books) Ltd., London, 1964, pp. 563-566.

18) A. B. Williams: A contribution to the life histories of commercial shrimp (Penaeidae) in north Carolina. Bull. Mar. Sci. Gulf and Carib., 5, 116-146 (1955).

19) K. S. Ko, M. Suzuki, and Y. Kondo: An Elementary study on Behaviour of common shrimp to moving net. Nippon Suisan Gakkaishi. 36, 556-562 (1970).

20）井伊明，井上喜平治，拓殖秀臣，小川良徳，内橋 潔：魚類の夜間行動に関する研究一II. 日水誌. 19, 239242 (1953).

21）東海 正, 伊東 弘, 山口義昭：小型底びき網（手綝第 3 種, 桁網）による異体類 3 種の網目選択性に関する予備 的検討. 南西水研研報, 22, 29-34 (1989). 